\title{
FAKTOR-FAKTOR PENDORONG DAN PENARIK CALON MAHASISWA MEMILIH JASA PENDIDIKAN TINGGI: STUDI KILAS BALIK
}

\author{
Grace Putlia \\ Manajemen, Universitas Bunda Mulia, Jakarta. \\ Alamat surel: gputlia@bundamulia.ac.id \\ John J.O.I. Ihalauw \\ Manajemen, Universitas Bunda Mulia, Jakarta. \\ Alamat surel: ihalauw@bundamulia.ac.id
}

\begin{abstract}
This retrospect study aims at studying the push and pull factors of prospective students in choosing higher education services of the management program of study at Satya Wacana Christian University. This retrospect study uses grounded theory design with triangulation of data sources. The findings showed three push factors, namely suitable benefit offered, prospect's motivation, and trusted recommendation. Twelve pull factors include service availability, promotion-mix, location, service quality, relationship, reputation, communication, process, price, human resources, facility, and guarantee. A mini-theory comprising of a set of 17 propositions is proposed to be further tested in future.
\end{abstract}

Keywords: push factor, pull factor, mini-theory

\section{Pendahuluan}

\section{Latar Belakang Masalah}

Setiap penelitian

dilatarbelakangi oleh sebuah situasi

problematik tertentu, yaitu hal, keadaan, pikiran, peristiwa atau objek tertentu yang gagasan-gagasan tentangnya masih kabur, sehingga memicu rasa keingintahuan ilmuwan dan peneliti untuk memahami, mendeskripsi, menjelaskan, ataupun meramalkan (Ihalauw, 2008).

Penelitian ini dipicu oleh fenomena empirik yang teramati, di mana calon mahasiswa dari luar kota Salatiga memilih jasa pendidikan tinggi yang ditawarkan program studi manajemen Fakultas Ekonomika dan Bisnis/FEB, Universitas Kristen Satya Wacana/UKSW ketimbang jasa yang sama atau mirip di tempat asal calon mahasiswa yang bersangkutan. Maka apa alasan mereka memilih jasa pendidikan tinggi di program studi manajemen FEB UKSW merupakan sebuah fenomena menarik apabila didalami menggunakan perspektif pemasaran dengan studi kilas balik. Studi kilas balik (retrospektif) yaitu penelitian yang mendeskripsikan hasil berupa data, dan dilakukan dengan menelusur rekam jejak yang ada (Andreas, 2010).
Sri Maryati (2009), menyatakan bahwa pergerakan menuju suatu tempat pembelajaran karena dua alasan, yaitu: (1) faktor intern, berasal dari masyarakat itu sendiri yang disebut sebagai faktor pendorong dan (2) faktor dari luar, yang dimiliki tempat pembelajaran disebut sebagai faktor penarik.

FEB didirikan pada tanggal 5 Desember 1959 di lingkungan UKSW, berlokasi di Jalan Diponegoro 52-60 Salatiga. Saat ini, FEB UKSW memiliki tiga program studi yaitu Program Studi Manajemen, Ilmu Ekonomi, dan Akuntansi (http://feb.uksw.edu).

Lima daerah yang mendominasi jumlah mahasiswa S1, S2, dan S3 berasal dari daerah Jawa Tengah, Jawa Barat, Lampung, Jawa Timur, dan Maluku. Setelah ditelusur lebih lanjut persentasi jumlah mahasiswa dari luar kota Salatiga memang lebih dominan.

Pada tahun 2009, mahasiswa dari kota Salatiga sebanyak $32,60 \%$, sedangkan yang berasal dari luar kota Salatiga sebanyak $67,40 \%$. Antusiasme mahasiswa dari luar kota Salatiga tampak dari meningkatnya persentasi pada tahun 2010 , menjadi $75,43 \%$, tetapi turun pada tahun $2011 ; 74,52 \%$, tahun 2012; 68,19\%, dan tahun 2013; 67,41\%. Persentasi mahasiswa dari luar kota Salatiga 
kembali meningkat pada tahun 2014, yaitu sebesar 71,54\% (Bagian Admisi dan Registrasi UKSW, 2015).

Jumlah mahasiswa manajemen program S1 pada tahun 2009 sebanyak 123 orang, tahun 2010; 130 orang, tahun 2011; 170 orang, tahun 2012; 217 orang, tahun 2013; 248 orang, dan tahun 2014; 295 orang. Jumlah mahasiswa manajemen program S2 pada tahun 2009 sebanyak 38 orang, tahun 2010; 36, tahun 2011; 48 orang, tahun 2012; 50 orang, tahun 2013; 47 orang, dan tahun 2014; 58 orang. Jumlah mahasiswa program manajemen S3 pada tahun 2009 sebanyak 6 orang, tahun $2010 ; 7$ orang, tahun $2011 ; 5$ orang, tahun 2012; 28 orang, namun dua tahun berikutnya secara berturut-turut mengalami penurunan. Pada tahun 2013 menjadi 23 orang dan tahun 2014 menjadi 16 orang.

Mahasiswa sebagai konsumen menentukan perkembangan suatu lembaga pendidikan tinggi. Oleh karena itu, lembaga pendidikan tinggi harus mengetahui faktorfaktor pendorong dan penarik yang menjadi pertimbangan calon mahasiswa ketika memilih jasa pendidikan tinggi untuk melanjutkan studi.

\section{Masalah dan Persoalan Penelitian}

Berdasarkan uraian di atas, masalah penelitian ini adalah faktor-faktor yang mendorong dan menarik calon mahasiswa dalam memilih jasa pendidikan tinggi di program studi manajemen FEB UKSW. Masalah penelitian diatas, dirinci dalam persoalan-persoalan penelitian berikut: (1) Faktor-faktor apa yang mendorong calon mahasiswa memilih jasa pendidikan tinggi di program studi manajemen FEB UKSW? (2) Faktor-faktor apa yang menarik calon mahasiswa memilih jasa pendidikan tinggi di program studi manajemen FEB UKSW?

\section{Tujuan Penelitian}

Tujuan penelitian ini: (1) Mendeskripsi faktor-faktor yang mendorong calon mahasiswa memilih jasa pendidikan tinggi di program studi manajemen FEB UKSW. (2) Mendeskripsi faktor-faktor yang menarik calon mahasiswa memilih jasa pendidikan tinggi di program studi manajemen FEB UKSW.

\section{Manfaat Penelitian}

Selain dari mencapai tujuan-tujuan di atas, penelitian memberi manfaat berikut:

(1) Penelitian ini akan membangun sebuah teori-mini. Jonker dan Pennink (2010), mengartikan teori mini sebagai berikut:

" $a$ theory that is applicable for one particular situation. It still needs to prove its general validity. By repeating the research the minitheory may develop into a theory that is useful in various situations and at particular times: a grand theory".

Melalui penelitian yang dilaksanakan berulang, teori-mini dapat berkembang menjadi sebuah teori yang berguna dalam berbagai situasi dan pada suatu waktu kelak dapat menjadi "grand theory".

(2) Hasil penelitian ini akan memberikan informasi bagi pengelola tentang kelebihan dan kekurangan program studi, dan berguna untuk melestarikan keunggulan kompetitif.

\section{Kajian Pustaka}

Kajian pustaka di bawah ini digunakan hanya sebagai pedoman.

\section{Jasa Pendidikan Tinggi}

Jasa umumnya dikonsumsi pada saat diproduksi, dan memberikan nilai tambah dalam bentuk: kenyamanan, hiburan, ketepatan waktu, kesehatan, dan lain-lain (Zeithaml dan Bitner, 2003).

Kotler dan Keller (2009), menyatakan jasa memiliki sejumlah karakteristik unik yang membedakannya dari barang yaitu: ketanwujudan ketidakterpisahan keragaman (intangibility), ketidaktahanlamaan (perishability). Jasa adalah setiap tindakan atau perbuatan yang dapat ditawarkan oleh suatu pihak kepada pihak lain yang pada dasarnya bersifat tanwujud (intangible) dan tidak menghasilkan kepemilikan sesuatu (Kotler dan Armstrong, 2010). 


\section{Perilaku Konsumen}

Suatu lembaga penyedia jasa pendidikan tinggi mempelajari dan memahami perilaku konsumen untuk memberikan petunjuk dalam mengembangkan jasa yang disediakan. Schiffman dan Kanuk (2000), mendefinisikan perilaku konsumen sebagai proses yang dilalui oleh seseorang dalam mencari, membeli, menggunakan, mengevaluasi, dan bertindak pasca konsumsi produk, jasa, maupun ide yang diharapkan bisa memenuhi kebutuhannya. Dengan kata lain, perilaku konsumen merupakan studi tentang bagaimana pembuat keputusan (individu, kelompok atau organisasi) membuat keputusan-keputusan pembelian suatu produk dan mengonsumsinya (Prasetijo dan Ihalauw, 2005).

Schiffman dan Kanuk kembali menyatakan bahwa studi perilaku konsumen merupakan pembelajaran tentang bagaimana masing-masing individu membuat keputusan dalam membelanjakan sumber dayanya (uang, waktu, tenaga) melalui proses pemecahan masalah.

\section{Penelitian Terdahulu}

Penelusuran terhadap pustaka ilmiah menemukan beberapa penelitian terdahulu yang telah membahas faktor-faktor pendorong dan penarik yang disajikan dalam Tabel 1:

Tabel 1 - Penelitian Terdahulu Mengenai Faktor-Faktor Pendorong dan Penarik

\begin{tabular}{|c|c|c|}
\hline No. & Judul Penelitian & Sumber \\
\hline 1. & Push-Pull Factors Influencing International Student Destination Choice. & Tim dan Geoffrey, 2001. \\
\hline 2. & Students' preferences for university: a conjoint analysis. & Geoffrey dan Julia, 2002. \\
\hline 3. & $\begin{array}{l}\text { Faktor-faktor yang Mendorong Mahasiswa Jurusan Akuntansi Program } \\
\text { Strata } 1 \text { Memilih Fakultas Ekonomi Universitas Widyatama (Survey } \\
\text { Pada Fakultas Ekonomi Universitas Widyatama). }\end{array}$ & Nuryaman, 2006. \\
\hline 4. & $\begin{array}{l}\text { Destination choice, service quality, satisfaction, and consumerism: } \\
\text { International students in Malaysian institutions of higher education. }\end{array}$ & Yet et al., 2011. \\
\hline 5. & Edutourism: Exploring The Push-Pull Factors In Selecting A University. & Jason et al., 2011. \\
\hline 6. & $\begin{array}{l}\text { Student choice in higher education: motivations for choosing to study at } \\
\text { an international branch campus. }\end{array}$ & Stephen et al., 2012. \\
\hline 7. & Factors influencing choice of a university by students in Zimbabwe. & Shepherd, 2013. \\
\hline 8. & Foreign students' motivation for studying in Malaysia. & Muhammad et al., 2013. \\
\hline 9. & Does 'Voyage Image' Affect Overseas Education Choice? & Jason et al., 2014. \\
\hline 10. & The Push and Pull Factors of Choosing a Study Location. & Kuranchie et al., 2014. \\
\hline
\end{tabular}

Tabel di atas jelas memperlihatkan bahwa sebagian besar penelitian mengarah pada pendidikan tinggi ke luar negeri, sedangkan yang dilakukan di dalam negeri masih terbatas. Penelitian-penelitian di atas menyatakan bahwa faktor pendorong antara lain: keinginan pribadi, orangtua, masalah politik, ekonomi dan militer dari negara asal. Faktor penarik terkait dengan hal-hal seperti reputasi, ketersediaan program, biaya, dan prospek kerja.

\section{Faktor-faktor Pendorong dan Penarik}

Lewis (1982), menyatakan bahwa ada beberapa faktor di daerah asal yang memicu seseorang untuk meninggalkan daerah asalnya, namun ada juga faktor-faktor di tempat tujuan yang dapat menarik seseorang untuk berpindah meninggalkan daerah asalnya. Sri Maryati (2009), menyebut: (1) faktor intern yang berasal dari masyarakat itu sendiri yang disebut sebagai faktor pendorong dan (2) faktor dari luar yang dimiliki tempat pembelajaran disebut sebagai faktor penarik.

Faktor-faktor pendorong dan penarik yang diduga dapat memengaruhi dalam pemilihan penyedia jasa pendidikan tinggi adalah sebagai berikut:

Faktor Pendorong:

Motivasi. Sadirman (2007) menyebutkan motivasi berasal dari motif. Motif dapat diartikan sebagai daya upaya yang mendorong seseorang untuk melakukan sesuatu. Bahkan motif dapat dikatakan sebagai suatu kondisi intern. Berawal dari motif, maka motivasi dapat diartikan sebagai 
daya penggerak yang telah menjadi aktif. Hal-hal terkait motivasi adalah:

a. Cita-cita. Fatahillah (2005), menjelaskan bahwa cita-cita bukan hanya terkait dengan sebuah profesi, namun lebih dari itu adalah sebuah tujuan hidup. Cita-cita merupakan bagian atau salah satu unsur dari pandangan hidup manusia, yaitu sesuatu yang ingin digapai oleh manusia melalui usaha. Sesuatu bisa disebut dengan cita-cita apabila telah terjadi usaha untuk mewujudkan sesuatu yang dianggap cita-cita itu.

b. Ketidaktersediaan Jasa.

Ketidaktersediaan jasa dalam hal ini adalah tidak tersedianya program studi yang diinginkan di tempat asal. Ghufron (2010), mendefinisikan program studi sebagai unit atau lembaga penyelenggara yang memiliki tugas melaksanakan pendidikan akademik dan/atau profesional sesuai kurikulum dan karakteristik satu atau bagian dari cabang keilmuan tertentu.

c. Rekomendasi. Menurut Febri (2009), rekomendasi adalah saran yang menganjurkan, membenarkan dan menguatkan. Pihak-pihak yang dapat memberikan rekomendasi sesuai dengan maksud penelitian ini misalnya orang tua, saudara, teman atau relasi yang memiliki pengalaman atau pengetahuan mengenai lembaga pendidikan dan/atau program studi tertentu.

Faktor Penarik:

1. Jasa yang Ditawarkan. Keputusan yang paling mendasar bagi suatu lembaga pendidikan adalah menentukan jasa yang akan ditawarkan, berdasarkan pertimbangan:

a. Sumber Daya Insani. Menurut Lupiyoadi (2001), seluruh sumber daya insani yang terlibat dalam pemberian program pendidikan dan jasa lainnya terdiri-dari: Pengelola yaitu pemegang utama kendali manajemen, yang didukung para pejabat struktural, mulai dari Rektor, sampai dengan Ketua Program Studi. Staf akademik yang melakukan pekerjaan mengajar, meneliti dan menjalankan layanan masyarakat. Staf pendukung yang meliputi pekerja profesional dibidang tertentu, seperti staf administrasi, keamanan, teknis, dan lain-lain.

b. Harga yang Ditetapkan. Kotler dan Fox (1999) menjelaskan bahwa penetapan harga sangat penting karena lembaga pendidikan bergantung kepada uang sekolah dan uang jasa lainnya untuk kegiatan operasionalnya. Menurut mereka hal yang perlu dipertimbangkan dalam penetapan harga adalah: dampak penetapan harga terhadap kondisi dan misi lembaga, jumlah pendaftar, peningkatan pertumbuhan, harga bersaing dibandingkan lembaga lain, dan dampak tingkat harga itu sendiri terhadap lembaga pesaing untuk mengubah harga.

c. Gelar Akademik. Menurut Peraturan Akademik Pendidikan (2011) Pasal 1 Nomor 32, gelar akademik adalah gelar yang diberikan kepada lulusan perguruan tinggi yang menyelenggarakan pendidikan akademik.

d. Prospek Kerja. Program studi ekonomi manajemen dikenal memberikan peluang lapangan kerja yang sangat luas dan masa depan cerah, dikarenakan lulusan program studi ini sangat lentur dan dapat ditempatkan dibanyak bidang lainnya. Ndraha (1998), menyatakan prospek kerja yang ditawarkan oleh pihak lembaga pendidikan tinggi setelah lulus merupakan salah satu daya pikat bagi calon mahasiswa.

2. Pemasaran. Konsep pemasaran berorientasi jangka panjang, menekankan pada kepuasan konsumen. Lembaga pendidikan harus tahu dengan tepat apa yang harus dilakukan, bukan hanya menyelenggarakan kegiatan belajarmengajar. Lebih dari itu, konsumen harus puas dengan layanan yang diberikan, misalnya:

a. Jasa Komunikasi. Gambaran tugas komunikasi yang dihadapi oleh lembaga pendidikan menurut Kotler 
dan Fox (1999) adalah: memelihara dan meningkatkan citra dari lembaga, membangun dukungan dan loyalitas alumni, menarik para donatur, menyediakan informasi tentang tawaran dari suatu program, menarik calon siswa dan meningkatkan pendaftaran, dan mengoreksi informasi yang tidak tepat atau tidak lengkap tentang lembaga.

b. Infrastruktur dan Fasilitas. Payne (2001), mengatakan seluruh kegiatan kerja termasuk infrastruktur adalah proses. Proses-proses meliputi: prosedur, tugas, jadwal, mekanisme, kegiatan dan rutin dimana suatu produk atau jasa disampaikan kepada pelanggan. Hal ini merupakan aspek kunci penyempurnaan kualitas jasa. Yazid (2001), mengemukakan bahwa bukti jasa mencakup representasi wujud tentang jasa. Sarana pengajaran dan kegiatan kemahasiswaan seperti sarana olahraga, kelengkapan laboratorium, whiteboard dan lain-lain. Prasarana pendidikan seperti luas gedung, kelas ber-AC, toilet, tempat parkir, ruang kantor, dan lain-lain.

c. Lokasi. Lokasi adalah tempat yang tetap di mana lembaga pendidikan menyelenggarakan

program pendidikan yang diterima oleh siswa (Ndraha, 1998).

\section{Metode Penelitian}

Grounded theory, digunakan untuk menghasilkan teori melalui proses pengumpulan data, analisis sistematis dan berkelanjutan dari data empirik. Penelitian ini menggunakan pendekatan Straussian yang didasari interaksi antara peneliti dengan data yang diteliti, sehingga akan didapat gambaran yang lebih jelas mengenai fenomena yang diteliti.

Penelitian dilakukan di FEB UKSW. Berbekalkan pedoman wawancara, wawancara mendalam dilaksanakan dengan informan-kunci yang mengetahui dan memiliki berbagai informasi pokok yang diperlukan penelitian ini (Hendrarso dan Susanti, 2005). Informan-kunci terdiri dari
24 mahasiswa jenjang S1, S2, dan S3. Data yang berhasil dihimpun telah mencapai titik jenuh, karena informan-kunci sudah tidak memberi informasi baru lagi (Hamidi, 2004).

Jenis data yang digunakan dalam penelitian ini, yaitu data primer dan data sekunder. Memperhatikan triangulasi data, maka data primer diperoleh melalui wawancara mendalam dan observasi, sedangkan data sekunder diperoleh melalui telusur pustaka, ataupun dokumentasi berupa rekaman audio-visual, teks ataupun gambar dari informan-kunci untuk memperkuat dan memperkaya data primer.

Menurut Sugiyono (2010), dalam penelitian kualitatif kriteria utama terhadap data hasil penelitian adalah sahih, andal, dan obyektif. Dalam penelitian ini, kesahihan diuji dengan taktik triangulasi sumber data. Uji keandalan data dilakukan dengan taktik audit trails atau audit rekam jejak penelitian. Menurut Daymon dan Holloway (2011), trail merupakan rekaman rinci dari keputusankeputusan yang dibuat sebelum dan selama penelitian, dan gambaran mengenai proses penelitian.

Analisis data dalam penelitian ini dilakukan melalui beberapa tahapan (Ihalauw, Gouw, dan Trita, 2011):

a. Transkripsi data, dimulai sesegera sesudah wawancara mendalam, observasi, dan dokumentasi dilakukan. Rekaman hasil wawancara diubah ke dalam bentuk teks, observasi ke dalam bentuk catatan, dan setiap data dokumentasi diberikan tema.

b. Pengodean data, merupakan proses analisis yang fundamental bagi penelitian (Corbin dan Strauss, 1990). Dalam penelitian grounded theory, pengodean data ialah kategorisasi segmen-segmen dalam data dengan suatu nama singkat yang secara utuh meringkas dan merepresentasikan setiap bagian dari data (Charmaz, 2006). Penelitian ini menggunakan teknik several sentence coding, sedangkan untuk data observasi dan dokumentasi digunakan teknik whole document coding. Pengodean data disajikan dalam trail 1, namun tidak diikutkan dalam tulisan ini karena keterbatasan halaman. 
c. Kategorisasi data. Pengodean data wawancara setiap informan-kunci dimasukkan ke dalam tabel, dan selanjutnya dilakukan analisis komparatif secara horizontal, hingga menghasilkan kategori-kategori jawaban dari setiap pertanyaan penelitian. Tahapan ini disajikan dalam trail 2 yang tidak diikutkan dalam tulisan ini.

d. Klasterisasi kategori. Selanjutnya dilakukan analisis kompararif secara vertikal, dimana setiap kategori yang merepresentasikan fenomena yang sama dikelompokkan ke dalam satu klaster. Trail 3 tidak diikutkan dalam tulisan ini.

e. Identifikasi pola dan konsep. Klasterklaster kategori jawaban diabstraksi menjadi pola, lalu diidentifikasi peubahpeubah atau konsep-konsep, yang selanjutnya akan menjadi komponen pembentuk proposisi dan teori-mini.

f. Pembentukan proposisi dan teori-mini. Konsep-konsep tersebut dikaitkan berdasarkan penalaran dan mungkin juga teori-teori yang telah ada untuk menjadi proposisi-proposisi. Proposisi-proposisi yang telah dibentuk selanjutnya dirangkai menjadi sebuah teori-mini.

\section{Hasil \\ Profil Informan-Kunci}

Seluruh informan-kunci berjumlah 24 mahasiswa. Informan-kunci program S1 yang berasal dari kota Salatiga 1 orang dan 9 orang lainnya berasal dari luar kota Salatiga yang terdiri dari angkatan 2010-2015. Informan-kunci program S2 yang berasal dari kota Salatiga 2 orang dan 9 orang berasal dari luar kota Salatiga, terdiri dari angkatan 2014-2015. Secara total terdapat 11 orang, dimana 4 orang di antaranya merupakan alumnus program S1 dari FEB UKSW. Informan-kunci manajemen program S3 yang berasal dari kota Salatiga 1 orang dan 2 lainnya berasal dari luar kota Salatiga, terdiri dari angkatan 2012 dan 2015, dimana 1 orang diantaranya merupakan alumnus program S2 dari FEB UKSW.

\section{Hasil Terkait Persoalan Penelitian Pertama}

Persoalan penelitian ini bertanya tentang faktor-faktor pendorong calon mahasiswa memilih jasa pendidikan tinggi. Data memperlihatkan tiga faktor yang mendorong dalam pemilihan jasa pendidikan tinggi. Hasil selengkapnya mengenai tiga faktor pendorong dirangkum dalam Tabel 2:

Tabel 2 Pesoalan Penelitian Pertama: Klaster Kategori Jawaban, Pola, dan Konsep

\begin{tabular}{|c|c|c|}
\hline Persoalan Penelitian 1 & $\begin{array}{c}\text { Klaster Kategori } \\
\text { Jawaban } \\
\end{array}$ & Pola dan Konsep \\
\hline $\begin{array}{l}\text { Faktor-faktor apa yang } \\
\text { mendorong calon } \\
\text { mahasiswa memilih } \\
\text { jasa pendidikan tinggi } \\
\text { di departemen } \\
\text { manajemen FEB } \\
\text { UKSW? }\end{array}$ & $\begin{array}{ll}\text { 1. } & \text { Kesesuaian } \\
& \text { Tawaran-Manfaat. } \\
\text { 2. } & \text { Motivasi Prospek } \\
\text { 3. } & \text { Rekomendasi } \\
& \text { Terpercaya. }\end{array}$ & $\begin{array}{l}\text { Prospek memilih jasa pendidikan tinggi dipicu } \\
\text { oleh adanya kesesuaian tawaran-manfaat. Kesesuaian } \\
\text { tawaran-manfaat akan menimbulkan motivasi prospek. } \\
\text { Hal-hal tersebut membuat calon mahasiswa sebagai } \\
\text { konsumen akan mencari informasi yang berkaitan dengan } \\
\text { kebutuhannya tersebut. Salah satu cara untuk } \\
\text { mendapatkan informasi bisa dengan rekomendasi } \\
\text { terpercaya. }\end{array}$ \\
\hline
\end{tabular}

Sumber: Data primer yang telah diolah dan direkam dalam trail 4 


\section{Hasil Terkait Persoalan Penelitian Kedua}

Persoalan penelitian kedua ingin mengetahui faktor-faktor penarik calon mahasiswa memilih jasa pendidikan tinggi. Berdasarkan data yang telah dianalisis, dapat diketahui 12 faktor penarik pemilihan jasa pendidikan tinggi. Secara lebih jelas, 12 faktor penarik tersebut dirangkum dalam Tabel 3:

Tabel 3

Persoalan Penelitian Kedua: Klaster Kategori Jawaban, Pola dan Konsep

\begin{tabular}{|c|c|c|}
\hline Persoalan Penelitian 2 & $\begin{array}{c}\text { Klaster Kategori } \\
\text { Jawaban }\end{array}$ & Pola dan Konsep \\
\hline $\begin{array}{l}\text { Faktor-faktor apa yang } \\
\text { menarik calon } \\
\text { mahasiswa memilih } \\
\text { jasa pendidikan tinggi } \\
\text { di departemen } \\
\text { manajemen FEB } \\
\text { UKSW? }\end{array}$ & $\begin{array}{l}\text { 1. Ketersediaan Jasa. } \\
\text { 2. Bauran Promosi. } \\
\text { 3. Lokasi. } \\
\text { 4. Kualitas Jasa. } \\
\text { 5. Keterhubungan. } \\
\text { 6. Reputasi. } \\
\text { 7. Komunikasi. } \\
\text { 8. Proses. } \\
\text { 9. Harga. } \\
\text { 10. Sumber Daya } \\
\text { Insani. } \\
\text { 11. Fasilitas. } \\
\text { 12. Jaminan. }\end{array}$ & $\begin{array}{l}\text { Persaingan antar penyedia jasa pendidikan tinggi } \\
\text { untuk menarik calon mahasiswa baru saat ini tidak } \\
\text { terhindarkan. Hal tersebut memicu penyedia jasa } \\
\text { pendidikan tinggi untuk menetapkan strategi agar } \\
\text { dapat menyesuaikan diri. Penyedia jasa perlu } \\
\text { menyediakan jasa yang sesuai untuk dapat } \\
\text { memenuhi kebutuhan atau keinginan pihak prospek. } \\
\text { Ketika ketersediaan jasa tercipta, hal tersebut perlu } \\
\text { diperkenalkan pada pihak prospek, salah satu } \\
\text { caranya dengan menggunakan bauran promosi. Pada } \\
\text { hakikatnya, bauran promosi dapat menciptakan } \\
\text { kesadaran akan adanya jasa, hingga akhirnya } \\
\text { memicu pembelian. } \\
\text { Bauran promosi akan menjelaskan segala } \\
\text { sesuatu mengenai jasa yang ditawarkan berupa } \\
\text { keunggulan-keunggulan yang menarik prospek, } \\
\text { meliputi: lokasi terlaksananya pembelajaran, kualitas } \\
\text { jasa, keterhubungan, reputasi baik, komunikasi, } \\
\text { proses pembelajaran, harga yang ditetapkan, sumber } \\
\text { daya insani yang dimiliki, fasilitas memadai, serta } \\
\text { jaminan pada pihak prospek dalam konteks konsumsi } \\
\text { jasa. }\end{array}$ \\
\hline
\end{tabular}

Sumber: Data primer yang diolah dan direkam dalam trail 4

\section{Pembahasan}

Berdasarkan hasil penelitian yang diuraikan di atas, dapat diidentifikasi beberapa konsep berikut dari persoalan penelitian pertama, yaitu tentang faktor pendorong: Kesesuaian tawaran-manfaat didefinisikan sebagai kemampuan organisasi dalam menyediakan produk atau jasa yang sejatinya dicari karena dibutuhkan dan diinginkan prospek. Kesesuaian tawaranmanfaat akan menimbulkan motivasi prospek, dimana motivasi prospek dipahami sebagai hasrat yang memicu tindakan seseorang di masa depan untuk memenuhi kebutuhan atau keinginan. Hal-hal tersebut akan membuat prospek mencari informasi berkaitan dengan kebutuhan atau keinginannya tersebut. Salah satu caranya dengan rekomendasi terpercaya yang didefinisikan sebagai pernyataan seseorang yang dapat diandalkan tentang sesuatu yang baik dan layak untuk dipilih.

Berdasarkan hasil penelitian terkait persoalan penelitian kedua tentang faktorfaktor penarik maka dapat diidentifikasi beberapa konsep berikut: Penyedia jasa perlu menyediakan jasa yang sesuai bagi prospek. Ketersediaan jasa menurut Asep (2005), adalah kondisi yang tercipta dari adanya sejumlah jasa, sehingga menimbulkan banyaknya pilihan. Ketika ketersediaan jasa tercipta maka penyedia jasa dapat menggunakan bauran promosi untuk memperkenalkan pada prospek. Bauran promosi adalah perpaduan khusus dari periklanan, promosi penjualan, penjualan pribadi, dan publisitas untuk pemasaran (Kotler dan Armstrong, 2001). Bauran promosi akan menjelaskan segala sesuatu tentang jasa yang ditawarkan, meliputi: lokasi didefinisikan sebagai tempat yang 
tetap dimana institusi pendidikan menyelenggarakan program pendidikan yang diterima oleh siswa (Ndraha, 1998). Kualitas jasa menunjuk pada total pengalaman yang hanya dapat dievaluasi oleh pelanggan (Zeithmal, 2000). Keterhubungan diartikan sebagai jumlah dari seluruh pengetahuan, pengalaman, dan kepercayaan yang dimiliki oleh sebuah organisasi terhadap para pelanggan, karyawan, dan mitra-mitranya (Kotler, 2003). Reputasi yaitu persepsi publik terkait tindakan-tindakan organisasi (Basya dan Sati, 2006). Komunikasi menurut Rogers dan Lawrence (1981), adalah suatu interaksi dimana terdapat dua orang atau lebih yang sedang membangun atau melakukan pertukaran informasi satu sama lain, sehingga pada akhirnya saling memahami dan mengerti. Proses menunjuk pada seluruh kegiatan kerja termasuk infrastruktur (Payne, 2001). Harga adalah sejumlah uang yang dibebankan atas suatu produk atau jasa (Kotler dan Armstrong, 2001). Sumber daya insani yaitu pelaku jasa yang memiliki dampak langsung pada hasil yang diterima pelanggan (Kotler dan Keller, 2006). Fasilitas menunjuk pada bukti jasa mencakup representasi keberwujudan (Yazid, 2001). Jaminan oleh Dutka (1995), didefinisikan sebagai garansi yang diberikan oleh badan usaha dengan harapan dapat memuaskan pelanggannya.

\section{Proposisi dan Teori Mini}

Manfaat yang hendak dicapai dalam penelitian ini adalah membangun sebuah teori- mini tentang faktor pendorong dan faktor penarik calon mahasiswa memilih jasa pendidikan tinggi. Teori-mini dapat dibangun dengan jalan mengaitkan proposisi-proposisi, sehingga menjadi sebuah rangkaian yang terpadu (Ihalauw, 2008).

\section{Proposisi}

Sistem penyampaian ketersediaan jasa salah satunya bisa dengan bauran promosi. Bauran promosi merupakan semua kegiatan yang dilakukan perusahaan untuk mengomunikasikan dan mempromosikan produknya kepada pasar sasaran (Teguh, 2002). Pernyataan tersebut sejalan dengan definisi bauran promosi (Kotler dan
Armstrong, 2001), yaitu perpaduan khusus dari periklanan, promosi penjualan, penjualan pribadi dan publisitas untuk pemasaran. Berlandaskan uraian di atas, diperoleh rumusan proposisi sebagai berikut:

\section{Proposisi 1:}

Semakin banyak ketersediaan jasa yang ditawarkan, maka semakin banyak bauran promosi yang dilakukan.

Adanya kesesuaian tawaran-manfaat akan menimbulkan motivasi prospek. Hal ini sesuai dengan yang diungkapkan oleh Nurudin (1997), bahwa seorang calon mahasiswa dikarenakan cita-cita menjadi haus akan pengetahuan yang lebih tinggi dan luas. Kemudian perguruan tinggi dianggapnya sebagai sarana untuk proses pencarian ilmu. Melalui pemaparan di atas, dirumuskan proposisi berikut:

Proposisi 2:

Semakin tinggi kesesuaian tawaran manfaat, maka semakin tinggi motivasi prospek.

Lokasi berperan sebagai peubah pemoderasi, yaitu peubah yang dapat memperkuat pengaruh antara peubah bebas yaitu motivasi prospek dengan peubah gayut yaitu pilihan jasa pendidikan tinggi. Artinya, lokasi yang strategis akan meningkatkan pengaruh motivasi prospek dalam melakukan pilihan jasa pendidikan tinggi. Melalui pemaparan di atas, diperoleh proposisi berikut:

Proposisi 3:

Semakin strategis lokasi, semakin meningkatkan pengaruh motivasi prospek terhadap pilihan jasa pendidikan tinggi. 
Kualitas jasa merupakan tolok ukur dalam menentukan keputusan seorang pengguna jasa, karena melalui kualitas jasa prospek akan dapat menilai kinerja, dan merasakan puas atau tidaknya layanan yang diberikan oleh penyedia jasa. Jika kualitas dari suatu jasa baik, tentu semakin banyak orang yang menginginkannya. Pemaparan di atas menghasilkan proposisi sebagai berikut:

\section{Proposisi 4:}

Semakin tinggi kualitas jasa yang ditawarkan, maka semakin banyak prospek melakukan pilihan jasa pendidikan tinggi.

Dua konsep berikut yang dapat diusulkan untuk ditautkan adalah kualitas jasa dan rekomendasi terpercaya. Apabila ada suatu kondisi yang dapat memenuhi atau bahkan melebihi harapan, maka akan memunculkan preferensi bagi pihak prospek, terlebih lagi jika ada seseorang yang berusaha untuk merekomendasikan hal itu kepada prospek tersebut. Proposisi yang dibentuk adalah sebagai berikut:

\section{Proposisi 5:}

Semakin tinggi kualitas jasa yang ditawarkan, maka semakin banyak rekomendasi terpercaya.

Mencermati definisi Kotler (2003) tentang keterhubungan yang disesuaikan dengan konteks penelitian, maka seseorang yang memiliki keterhubungan baik tentunya akan memunculkan banyak rekomendasi terpercaya. Rekomendasi terpercaya didefinisikan sebagai tindakan handal seseorang yang mengatakan bahwa ada sesuatu yang baik dan layak untuk dipilih. Melalui pemaparan di atas, diperoleh proposisi sebagai berikut:

Proposisi 6:

Semakin luas keterhubungan yang
terjalin, maka semakin banyak
rekomendasi terpercaya.

Reputasi oleh Basya dan Sati (2006) didefinisikan sebagai persepsi publik terkait tindakan-tindakan organisasi. Apabila persepsi yang dimiliki oleh seseorang bagus terhadap suatu jasa tertentu, maka akan merekomendasikan hal tersebut kepada pihak lain. Penjelasan singkat di atas menghasilkan proposisi sebagai berikut:

\section{Proposisi 7:}

Semakin baik reputasi jasa, maka semakin banyak rekomendasi terpercaya.

Jika reputasi yang merupakan persepsi seseorang dari suatu jasa bagus, tentu semakin banyak orang yang menginginkannya. Hal ini sejalan dengan yang diungkapkan Keller (1992), bahwa dua hal utama tentang reputasi perusahaan yang berhubungan dengan atribut produk adalah kualitas bagus dan inovatif. Proposisi yang terbentuk adalah berikut ini:

\section{Proposisi 8:}

Semakin baik reputasi jasa, maka semakin banyak prospek melakukan pilihan jasa pendidikan tinggi.

Rogers dan Lawrence (1981), mendefinisikan komunikasi sebagai suatu interaksi dimana terdapat dua orang atau lebih yang sedang membangun atau melakukan pertukaran informasi satu sama lain yang pada akhirnya saling memahami dan mengerti. Tidak ada proses yang akan terlaksana tanpa adanya komunikasi, penyaluran makna diantara satu orang ke orang lain. Tetapi komunikasi itu lebih dari sekedar menanamkan makna, melainkan juga harus dipahami (Robbins, 2001). Terjadinya proses yang baik tidak lepas dari adanya komunikasi yang baik pula. Penjelasan singkat di atas menghasilkan proposisi berikut:

\section{Proposisi 9:}

Semakin baik komunikasi penyedia layanan, maka semakin baik proses pembelajaran. 
Bauran promosi menunjuk pada sejumlah perpaduan khusus dari periklanan, promosi penjualan, penjualan pribadi, dan publisitas untuk pemasaran. Hal tersebut merupakan titik awal adanya kesadaran atas pemenuhan kebutuhan dan keinginan. Setelah pihak prospek menyadari kebutuhan dan keinginannya mereka akan menindaklanjuti untuk memenuhi kebutuhan dan keinginannya. Proposisi yang dapat dikemukakan adalah berikut ini:

\section{Proposisi 10:}

Semakin banyak bauran promosi yang dilakukan, maka semakin banyak prospek melakukan pilihan jasa pendidikan tinggi.

Motivasi prospek didefinisikan sebagai hasrat yang memengaruhi tindakan seseorang di masa depan untuk memenuhi kebutuhan atau keinginan. Cita-cita merupakan suatu motivasi prospek karena termasuk ke dalam tindakan seseorang di masa depan. Motivasi akan menjadikan atau memengaruhi kepribadian, sikap, tingkah laku dan orientasi baik sebelum, selama atau setelah menjadi mahasiswa (Nurudin, 1997). Melalui pemaparan di atas, diperoleh rumusan proposisi berikut:

\section{Proposisi 11:}

Semakin tinggi motivasi prospek, maka semakin banyak prospek melakukan pilihan jasa pendidikan tinggi.

James et al. (1994) menyatakan bahwa konsumen, dalam konteks ini adalah calon mahasiswa, sering meminta pendapat pada teman dalam pemilihan produk maupun jasa. Konsumen kerap berpaling kepada orang lain khususnya yang dipercaya seperti teman dan anggota keluarga untuk meminta pendapat mengenai produk dan jasa. Hal ini akan semakin memberikan rasa yakin untuk melakukan keputusan ketika diperhadapkan pada pilihan yang banyak. Uraian ini menghasilkan proposisi sebagai berikut:

\section{Proposisi 12:}

Semakin banyak rekomendasi terpercaya, maka semakin banyak prospek melakukan pilihan jasa pendidikan tinggi.
Menurut Payne (2001), proses diartikan sebagai seluruh kegiatan kerja termasuk infrastruktur. Apabila seluruh proses atau kegiatan kerja dan infrastruktur yang ditawarkan baik, tentunya akan ada banyak peminat. Melalui pemaparan di atas, diperoleh rumusan proposisi sebagai berikut:

\section{Proposisi 13:}

Semakin baik proses pembelajaran, maka semakin banyak prospek melakukan pilihan jasa pendidikan tinggi.

Tingginya harga yang ditetapkan bisa merupakan keharusan karena biaya untuk mendidik setiap mahasiswa memang tinggi. Penetapan harga bagi lembaga pendidikan sangat penting karena mereka bergantung kepada uang sekolah dan uang jasa lainnya demi mendukung kegiatan operasional. Orangtua dan/atau prospek akan mencari harga yang ideal bagi mereka untuk suatu penawaran yang ada, sehingga diperoleh proposisi sebagai berikut:

\section{Proposisi 14:}

Semakin terjangkau harga yang ditawarkan, maka semakin banyak prospek melakukan pilihan jasa pendidikan tinggi.

Sumber daya insani yang terlibat dalam pemberian jasa layanan memiliki dampak langsung pada hasil yang diterima pelanggan. Oleh karena itu kualitas yang tinggi dari sumber daya insani perlu dimiliki oleh penyedia jasa. Melalui pemaparan di atas, diperoleh rumusan proposisi sebagai berikut:

\section{Proposisi 15:}

Semakin tinggi kualitas sumber daya insani yang dimiliki, maka semakin banyak prospek melakukan pilihan jasa pendidikan tinggi. 
Calon pengguna jasa pendidikan tinggi yang akan memilih penyedia jasa pendidikan tinggi pasti mempertimbangkan juga fasilitas yang tersedia. Tidak mengherankan jika pemasaran jasa menekankan tentang pentingnya bukti-bukti fisik yang berwujud. Proposisi yang dapat diusulkan sebagai berikut:

\section{Proposisi 16:}

Semakin baik fasilitas yang ada, maka semakin banyak prospek melakukan pilihan jasa pendidikan tinggi.
Penyedia jasa pendidikan tinggi yang terkenal akan didatangi oleh banyak perusahaan yang mengadakan seleksi penerimaan pegawai terhadap mahasiswa tingkat akhir atau para lulusan. Prospek kerja yang ditawarkan oleh penyedia jasa pendidikan tinggi setelah lulus merupakan salah satu daya pikat bagi calon mahasiswa. Proposisi yang terbentuk adalah sebagai berikut:

Proposisi 17:

Semakin tinggi jaminan yang diberikan, maka semakin banyak prospek melakukan pilihan jasa pendidikan tinggi.

Teori Mini

Berdasarkan 17 proposisi di atas, penulis membangun teori-mini seperti berikut:

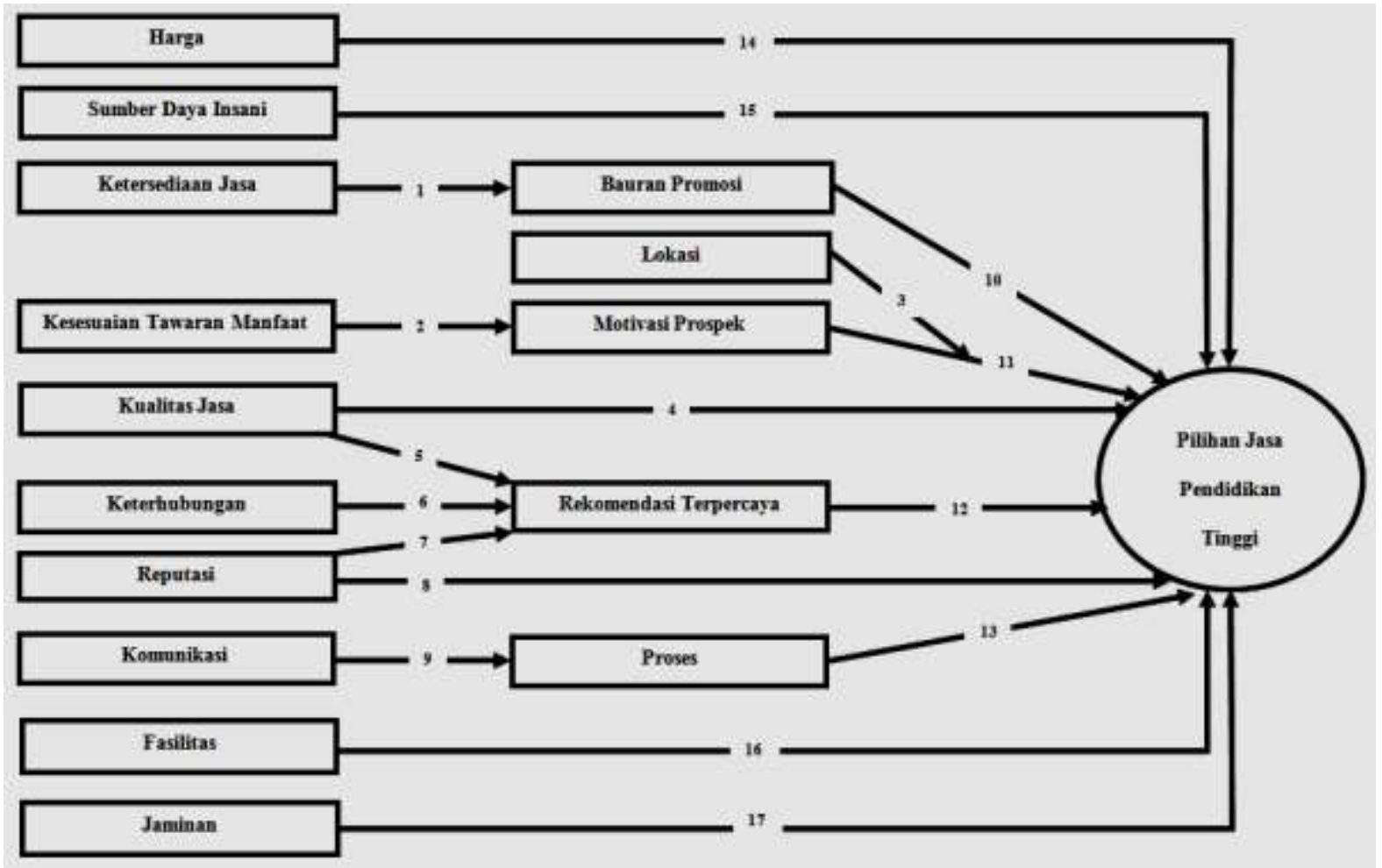

Gambar 1. Teori Mini

Sumber: Data primer yang diolah dan terekam dalam trail 5

\section{Kesimpulan dan Implikasi}

Hasil-hasil penelitian ini secara jelas menunjukkan bahwa pilihan jasa pendidikan tinggi di dalam negeri dipengaruhi oleh sejumlah peubah yang berperan sebagai faktor-faktor pendorong dan penarik terhadap prospek, yang dalam hal ini adalah para calon mahasiswa. Berdasarkan kesimpulan diatas, maka dapat disusun implikasi teoritis dan implikasi terapan dari penelitian ini.
Implikasi teoritis sehubungan dengan sumbangan penelitian bagi khasanah ilmu pengetahuan, sedangkan implikasi terapan memuat saran-saran bagi para pengelola.

1. Implikasi Teoritis. Sebagaimana dikemukakan di atas, penelitian ini hanya mengidentifikasi sejumlah peubah yang telah prospek gunakan sebagai pendorong dan penarik ketika memilih jasa pendidikan tinggi. Peubah-peubah mana 
yang sangat dominan ketika prospek membuat keputusan berada di luar jangkauan studi ini. Studi ini telah mengontribusi tiga konsep yaitu: kesesuaian tawaran-manfaat, motivasi prospek, dan rekomendasi terpercaya.

2. Implikasi Terapan. Penelitian ini memiliki implikasi terapan sebagai berikut:

a. Penyedia dan pengelola jasa pendidikan tinggi perlu secara serius memperhatikan kebutuhan dan keinginan pelanggan yang senantiasa berubah agar ketersediaan jasa dan kesesuaian tawaran manfaatnya cocok. Penerapan strategi pemasaran yang tepat juga tidak boleh terlewatkan untuk dapat meraih dan melestarikan keunggulan bersaing. Oleh karenanya, faktor pendorong dan faktor penarik yang dominan memengaruhi harus diketahui.

b. Agar kualitas dan reputasi penyedia jasa pendidikan tinggi tetap terjaga, dan mengingat perlunya kegiatan promosi, sebaiknya hal tersebut ditangani oleh tenaga pemasaran yang profesional, sehingga staf akademik dapat fokus pada kegiatan tridarma.

\section{Keterbatasan Penelitian dan Agenda Penelitian Mendatang}

Penelitian ini juga memiliki keterbatasan yang perlu diperhatikan dalam melakukan penelitian-penelitian sejenis di masa mendatang. Ketika berlangsung wawancara, informan-kunci diminta untuk mengingatingat kembali pengalamannya di waktu dulu. Ada kemungkinan beberapa informasi belum tentu mereka ingat dengan tepat. Akhirnya, penelitian mendatang dapat mengagendakan untuk menguji teori-mini dengan menggunakan pendekatan kuantitatif.

\section{Daftar Pustaka}

Andreas. 2010. Metode Penelitian Kualitatif: Aplikasi Praktis Pembuatan Proposal dan Laporan Penelitian. Universitas Airlangga Surabaya.

Asep, H. 2005. Penelitian Bisnis Paradigma Kuantitatif. Gramedia Media Sarana Indonesia. Jakarta.

Bagian Admisi dan Registrasi UKSW. 2015.

Basya dan Sati. 2006. Cultural and Communication Studies. Jalasutra. Yogyakarta.

Charmaz, K. 2006. Constructing Grounded Theory: A Practical Guide Through Qualitative Analysis. Sage. London.

Cobin, J., dan Strauss, A.L. 1990. Grounded Theory Research: Procedures, Canons, and Evaluative Criteria. Qualitative Sociology. Vol. 13. No. 1.

Daymon, C., dan Holloway, I. 2011. Qualitative Research Methods in Public Relations and Marketing Communications. Routledge. New York.

Dutka, A. 1995. AMA Handbook for Customer Satisfaction: A Complete Guide to Research, Planning and Implementation. NTC Business Books. Lincolnwood.

Fatahillah. 2005. Arti Sebuah Cita-cita. Balai Pustaka. Jakarta.

Febri. 2009. Konsep dan Rekomendasi untuk Implementasi Sistem Peringatan. Jurnal Sosial dan Budaya. Vol. 32. No. 2.

Geoffrey, N.S., dan Julia, P.T. 2002. Students' Preferences for University: a conjoint analysis. The International Journal of Educational Management. Vol. 16. No. 1, pp. 40-45.

Ghufron, A. 2010. Pengembangan Tatapamong Prodi. Fakultas Ilmu Pendidikan Universitas Negeri Yogyakarta. Yogyakarta. 
Hamidi. 2004. Metode Penelitian Kualitatif: Aplikasi Praktis Pembuatan Proposal dan Laporan Penelitian. UMM Press. Malang.

Hendrarso., dan Susanti, E. 2005. Penelitian Kualitatif: Sebuah Pengantar. Kencana. Jakarta.

Ihalauw, John JOI. 2008. Konstruksi Teori: Komponen dan Proses. Grasindo. Jakarta.

Ihalauw, John JOI., Gouw, W., dan Trita, Y. 2011. Dari Realitas Bisnis Мепији Ke Konstruksi Model. UPH. Jakarta.

James. 1994. Ekonomi Pariwisata, Sejarah dan Prospeknya. Fakultas Ilmu Pendidikan Universitas Negeri Yogyakarta. Yogyakarta.

Jason, M.S.L., Ahmad, A.M.A., dan Azhar, Hj.Ahmad. 2011. Edutourism: Exploring The Push-Pull Factors In Selecting A University. International Journal of Business and Society. Vol.12. No. 1, pp. 63-78.

Jason, M.S.L., Sook, F.Y., Seng, H.T., Venny, S.W., Chong., dan Yit, L.O. 2014. Does 'Voyage Image' Affect Overseas Education Choice?, Australian Journal of Basic and Applied Science. Vol. 8. No. 5, pp. 539-545.

Jonker, J., dan Pennink, B. 2010. The Essence of Research Methodology. Heidelberg: Springer.

Keller, R.L. 1992. Transformasional Leadership and The Reformance of Research and Development Project Groups. Journal Management, 18 (3): 489-501.

Kotler, P., dan Fox, A. 1999. Strategic Marketing for Educational Institutions. Prentice Hall.

Kotler, P., dan Armstrong. 2001. Prinsipprinsip Pemasaran. Edisi 8. Erlangga. Jakarta.

Kotler, P. 2003. Marketing Insights From A to Z. PT. Gelora Aksara Pratama. Jakarta.
Kotler, P., dan Keller, K.L. 2006. Manajemen Pemasaran. Ghalia. Indonesia. Jakarta.

Kotler, P., \& Keller, K.L. 2009. Principles of Marketing Pearson Education. USA.

Kotler, P., dan Armstrong. 2010. Principles Of Marketing. 13 Edition. Upper Saddle River: Pearson Prentice Hall. New Jersey.

Kuranchie, A., Sarkodie, N.A., dan Acquah, H.E. 2014. The Push and Pull Factors of Choosing a Study Location. International Journal of Applied Research and Studies. Vol. 3. No. 5, pp. 227-9480.

Lewis, G.J. 1982. Human Migration: $A$ Geographical Perspective. Croom Helm. London and Canberra, Australia.

Lupiyoadi, R. 2001. Manajemen Pemasaran Jasa. Salemba Empat. Jakarta.

Muhammad, Z., Sabbar, D.S., Shahid, B., dan Rai, I.H. 2013. Foreign Students' Motivation For Studying In Malaysia, International Journal of Asian Social Science. Vol. 3. No. 3, pp. 833-846.

Ndraha, T. 1998. Budaya Organisasi. Rineka Cipta. Jakarta.

Nurudin. 1997. Pemakaian Bahasa dalam Grafika di Kota Yogyakarta dan Sekitarnya. UGM - Yogyakarta. Yogyakarta.

Nuryaman. 2006. Faktor-faktor yang Mendorong Mahasiswa Jurusan Akuntansi Program Strata 1 memilih Fakultas Ekonomi Universitas Widyatama (Survey pada Fakultas Ekonomi Universitas Widyatama). Universitas Widyatama. Bandung.

Payne, A. 2001. The Essence Of Service Marketing. Andi dan Pearson Education (Asia) Pte. Ltd. Yogyakarta.

Peraturan Akademik Pendidikan Nomor 32 Tahun 2011. Depdiknas. Jakarta. 
Prasetijo, R., dan Ihalauw, John JOI. 2005. Perilaku Konsumen. ANDI. Yogyakarta.

Profil Fakultas Ekonomika dan Bisnis UKSW. 2016. Available at http://feb.uksw.edu/.

Robbins, S.P. 2001. Organizational Behavior. Prentice Hall. New Jersey.

Roger dan Lawrence. 1981. Communication Network Toward a New Paradigm for Research. The Free Press a Division of Macmillan Publishing. New York.

Sadirman. 2007. Interaksi dan Motivasi Belajar Mengajar. PT. Grafindo Persada. Jakarta.

Schiffman, L.G., dan Kanuk, L.L. 2000. Consumer Behavior. $7^{\text {th }}$ Edition. Prentice Hall. New Jersey.

Shepherd, M. 2013. Factors Influencing Choice of a University by Students in Zimbabwe. African Journal of Business Management. Vol. 7. No. 36, pp. 3723-3729.

Sri, M. 2009. Faktor-faktor yang Mempengaruhi Preferensi Masyarakat dalam Memilih Sekolah Menengah Kejuruan Negeri (SMKN) di Kota Semarang. Universitas Diponegoro. Semarang.

Stephen, W., Melodena, B.S.B., dan Jeroen, H. 2012. Student Choice in Higher Education: Motivations for Choosing to Study at an International Branch Campus, Journal of Studies in International Education. Vol. 16. No. 5, pp. 413-433.

Sugiyono. 2010. Memahami Penelitian Kualitatif. CV. Alfabeta. Bandung.

Teguh. 2002. Bauran Promosi. PT. Grafindo Persada. Jakarta.

Tim, M. dan Geoffrey, N.S. 2001. Push-Pull Factors Influencing International Student Destination Choice. The International Journal of Educational Management. Vol. 16. No. 2, pp. 82-90.
Yazid. 2001. Pemasaran Jasa: Konsep Dan Implementasi. Edisi Pertama. Ekonisia Fakultas Ekonomi. Yogyakarta.

Yet, M.L., Ching, S.Y., dan Teck, H.L. 2011. Destination Choice, Service Quality, Satisfaction, and Consumerism: International Students in Malaysian Instituitions of Higher Education. African Journal of Business Management. Vol. 5. No. 5, pp. 1691-1702.

Zeithaml, V.A. 2000. Service Marketing: Integrating Customer Focus Across. The Firm: Graw Hill.

Zeithaml, V. A., dan Bitner, M. J. 2003. Service Marketing. $3^{\text {rd }}$ Edition. Tata McGraw Hill, New Delhi. 